\title{
Lessons learnt from imported cases and onward transmission of Lassa fever in Europe support broader management of viral haemorrhagic fevers
}

\author{
Roger Hewson ${ }^{1,2}$ \\ 1. Public Health England, Porton Down, United Kingdom \\ 2. Faculty of Infectious Tropical Disease, London School of Hygiene \& Tropical Medicine, United Kingdom
}

Correspondence: Roger Hewson (Roger.Hewson@phe.gov.uk)

Citation style for this article:

Hewson Roger. Lessons learnt from imported cases and onward transmission of Lassa fever in Europe support broader management of viral haemorrhagic fevers. Euro Surveill. 2017;22(39):pii=17-00661. https://doi.org/10.2807/1560-7917.ES.2017.22.39.17-00661

Article submitted on 21 Sep 2017 / accepted on 27 Sep 2017 / published on 28 Sep 2017

Viral haemorrhagic fevers (VHFs) are severe and lifethreatening diseases that have been reported in parts of Africa, South America, the Middle East, Central Asia and Europe. They are capable of causing long-term and slow burning epidemics, which can interrupt normal life, trade and impact the social structure of a community [1]. The known viruses responsible for VHFs are not genetically related and are classified in disparate virus families; they include members of the Arenvirid ae, Flaviviridae, Filoviridae, Nairoviridae and Phenuvir idae (Table). They circulate in animal reservoirs and sometimes arthropod vectors; humans are not part of their natural life cycle, but incidental infection and introduction into the human population often results in an outbreak. VHFs are described as hazard or risk group 4 pathogens $[2,3]$ and warrant maximum laboratory containment facilities and working precautions i.e. containment or biosafety level 4 .

VHFs are of particular public health importance because they can spread within hospital and community settings; they have a high case fatality rate if left untreated; they are difficult to recognise and detect rapidly; and there is no specific treatment. In Europe, environmental conditions do not support the natural animal reservoirs or vectors of most of the haemorrhagic fever viruses, and in consequence the majority of recorded cases of VHF in Europe have been acquired overseas. A notable exception to this rule is the Crimean-Congo haemorrhagic fever virus which occasionally infects humans. It circulates unobtrusively between mammals and ticks in southern parts of west and eastern Europe [4]. Autochthonous cases of other VHFs have infrequently occurred in Europe and, with the exception of a laboratory worker who sustained a needle-stick injury in the United Kingdom (UK) in 1976 [5], these have been associated with transmission from index cases to healthcare workers $[6,7]$. Such incidents attract interest and ultimately help our understanding of disease transmission, leading to improvements in the risk assessment and management of VHFs. Over the past decade, Europe has faced a total of 21 different incursions of VHF [8-14].

In this issue of Eurosurveillance two articles by Lehmann et al. and Ehlkes et al. $[15,16]$ provide further insight to the VHF community by detailing the most recent importation of Lassa fever (LF) into Germany in 2016 and its onward transmission to an undertaker. The incident highlights difficulties and delays in the diagnosis of the index case, principally because the country where the infection was acquired - Togo - had not previously been known as an endemic area of Lassa fever virus (LASV). The index case died soon after admission and a post-mortem was performed. Although this did not disclose the immediate cause of death, liver sections displayed classic features of VHF, and LASV was subsequently detected in a laboratory test. Unfortunately, this diagnosis occurred after the patient, the body and tissue samples had come into contact with healthcare workers and others on multiple occasions in the absence of specific precautions required for a hazard group 4 pathogen. Extensive effort in contact tracing, risk categorisation, interviewing and reporting then ensued. Symptom monitoring in contacts was complicated by a peak in activity of the influenza season and plans to avoid the unnecessary triggering of enhanced control measures such as isolation or quarantine were developed with an underpinning and basic scientific knowledge of LASV and human disease. An undertaker, who had contact with the body 6 days after death, was identified at increased risk following interview and while an early PCR test for LASV was negative, he tested positive 12 days post exposure. The undertaker was subsequently treated with ribavirin and made a full recovery; it is unclear how he became infected. None of the other 76 contacts who were followed up in the two concerned German federal states, North-RhineWestphalia and Rhineland-Palatinate, were positive. 
Viruses known to cause viral haemorrhagic fever in humans

\begin{tabular}{|c|c|c|c|c|c|c|}
\hline $\begin{array}{l}\text { Virus taxonomy } \\
\text { VHF }\end{array}$ & $\begin{array}{l}\text { Reservoir } \\
\text { / vector }\end{array}$ & $\begin{array}{l}\text { Geographic } \\
\text { location / risk } \\
\text { areas }\end{array}$ & Disease & $\begin{array}{l}\text { Incubation } \\
\text { period } \\
\text { (days) }\end{array}$ & $\begin{array}{c}\text { Case } \\
\text { fatality } \\
\text { rate }^{\mathrm{a}}(\%)\end{array}$ & Reference \\
\hline \multicolumn{7}{|l|}{ Arenaviridae } \\
\hline Chapare mammarenavirus & Rodents $^{\mathrm{b}}$ & $\begin{array}{c}\text { South America / } \\
\text { Bolivia }\end{array}$ & Chapare HF & $7-14$ & $70^{a}$ & [13] \\
\hline Guanarito mammarenavirus & $\begin{array}{c}\text { Rodents Zygodontomys } \\
\text { brevicauda }\end{array}$ & \begin{tabular}{|c|}
$\begin{array}{c}\text { South America / } \\
\text { Venezuela }\end{array}$ \\
\end{tabular} & Venezuelan HF & $6-14$ & 36 & [14] \\
\hline Junín mammarenavirus & $\begin{array}{c}\text { Rodents } \\
\text { Calomys musculinus }\end{array}$ & $\begin{array}{c}\text { South America / } \\
\text { Argentina }\end{array}$ & Argentinian $\mathrm{HF}$ & $7-14$ & $3-15$ & {$[15]$} \\
\hline Lassa mammarenavirus & $\begin{array}{c}\text { Rodents } \\
\text { Mastomys natalensis }\end{array}$ & $\begin{array}{l}\text { West Africa / } \\
\text { Sub-Saharan } \\
\text { Africa }\end{array}$ & Lassa fever & $5-6$ & 1 & [16] \\
\hline Lujo mammarenavirus & Rodents $^{b}$ & $\begin{array}{l}\text { Sub-Saharan } \\
\text { Africa }\end{array}$ & Lujo HF & $7-14$ & 80 & {$[17]$} \\
\hline Machupo mammarenavirus & $\begin{array}{l}\text { Rodents } \\
\text { Calomys callosus }\end{array}$ & $\begin{array}{c}\text { South America / } \\
\text { Bolivia }\end{array}$ & Bolivian HF & $7-14$ & 25 & [18] \\
\hline Sabiá mammarenavirus & Rodents $^{\mathrm{b}}$ & $\begin{array}{c}\text { South America/ } \\
\text { Brazil }\end{array}$ & Brazilian HF & $7-14$ & $50^{a}$ & [19] \\
\hline \multicolumn{7}{|l|}{ Flaviviridae } \\
\hline Yellow fever virus & Monkeys / mosquitoes & $\begin{array}{l}\text { South America } \\
\text { and Africa }\end{array}$ & Yellow fever & $3-6$ & $20-50$ & [20] \\
\hline \multicolumn{7}{|l|}{ Filoviridae } \\
\hline Ebolavirus & Bats $^{b}$ & $\begin{array}{l}\text { Sub-Saharan } \\
\text { Africa }\end{array}$ & Ebola HF & $2-21$ & $50-80$ & [21] \\
\hline Marburg virus & $\begin{array}{c}\text { Fruit bats Rousettus } \\
\text { aegyptii }\end{array}$ & $\begin{array}{l}\text { Sub-Saharan } \\
\text { Africa }\end{array}$ & Marburg HF & $2-21$ & 80 & [21] \\
\hline \multicolumn{7}{|l|}{ Nairoviridae } \\
\hline $\begin{array}{l}\text { Crimean-Congo haemorrhagic fever } \\
\text { orthonairovirus }\end{array}$ & $\begin{array}{l}\text { Ticks / rodents and } \\
\text { ruminants }\end{array}$ & $\begin{array}{l}\text { Asia, Africa } \\
\text { Middle East } \\
\text { Europe }\end{array}$ & Crimean Congo HF & $1-3$ & $5-50$ & [22] \\
\hline \multicolumn{7}{|l|}{ Phenuiviridae } \\
\hline Rift Valley fever virus phlebovirus & $\begin{array}{l}\text { Livestock ruminants / } \\
\text { mosquitoes }\end{array}$ & $\begin{array}{l}\text { Sub-Saharan } \\
\text { Africa }\end{array}$ & Rift Valley fever & $2-6$ & 1 & [23] \\
\hline $\begin{array}{l}\text { Severe fever with } \\
\text { thrombocytopenia syndrome } \\
\text { phlebovirus }\end{array}$ & Deer / ticks & $\begin{array}{l}\text { China, South } \\
\text { Korea Japan }\end{array}$ & $\begin{array}{l}\text { Severe fever with } \\
\text { thrombocytopenia } \\
\text { syndrome }\end{array}$ & $7-14$ & $12-40$ & [24] \\
\hline
\end{tabular}

HF: haemorrhagic fever; VHF: viral haemorrhagic fever.

a Some case fatality rates are based on low numbers of cases.

${ }^{\mathrm{b}}$ Animal reservoirs suspected but not proven.

Following an international alert after the confirmed diagnosis of the index case, another secondary transmission was diagnosed in a healthcare professional who had cared for the index case in Togo. This patient was subsequently medevacked to the Unites States and made a full recovery following treatment.

The rodent reservoir of LASV - the Natal multimammate rat Mastomys natalensis - is not supported by environmental conditions in Europe and LF does not pose a significant public health threat in this continent. Nevertheless, LF cases are the most commonly imported of the VHFs into Europe, with 21 traveller-related incidents since the virus was discovered in 1969; interestingly, 13 of these were to the UK [17]. Given the long-standing deep-seated links with Europe and the role of European workers in humanitarian support in West Africa, LF cases will continue to be imported into Europe. Each incident places a substantial demand on clinical, laboratory and public health resources [18]. It is fitting therefore that scientific knowledge is continually developed, including a better understanding of similar emerging viruses [19-30]. Lessons learnt should be continually distilled into appropriate guidance so that future VHF incidents can be effectively managed 
and rapidly controlled as also pointed out by Ehlkes et al. and Lehmann et al..

From a global perspective, the ideal way to prevent imported infections would be to control the disease in West Africa. Rodent control and the reduction of contact between humans and rodents and their excreta will help to prevent infection. Other control measures such as vaccination may offer a more sustainable solution. Indeed LF has been prioritised for research and development in public health emergency contexts by the World Health Organization [31] and several international vaccine strategies are underway.

\section{Conflict of interest}

None declared.

\section{References}

1. Elston JW, Cartwright C, Ndumbi P, Wright J. The health impact of the 2014-15 Ebola outbreak. Public Health. 2017;143:60-70. https://doi.org/10.1016/j.puhe.2016.10.020 PMID: 28159028

2. Health and Safety Executive (HSE). The Approved List of biological agents. London: HSE; 2013. Available from: http:// www.hse.gov.uk/pubns/misc208.pdf

3. Directive 2000/54/EC of the European Parliament and of the Council of 18 September 2000 on the protection of workers from risks related to exposure to biological agents at work (seventh individual directive within the meaning of Article 16(1) of Directive 89/391/EEC). Luxembourg: Publications Office of the European Union; 17 Oct 2000. Available from: http://eurlex.europa.eu/legal-content/EN/TXT/?uri=celex:32000Lo054

4. European Centre for Disease Prevention and Control (ECDC). Rapid Risk Assessment. Crimean-Congo haemorrhagic fever in Spain. Stockholm: ECDC; 8 Sep 2016. Available from: https:// ecdc.europa.eu/sites/portal/files/media/en/publications/ Publications/crimean-congo-haemorrhagic-fever-spain-riskassessment.pdf

5. Emond RT, Evans B, Bowen ET, Lloyd G. A case of Ebola virus infection. BMJ. 1977;2(6086):541-4. https://doi.org/10.1136/ bmj.2.6086.541 PMID: 890413

6. World Health Organization (WHO). Ebola virus disease - Spain. Geneva: WHO; 9 Oct 2014. Available from: http://www.who.int/ csr/don/o9-october-2014-ebola/en/

7. Negredo A, de la Calle-Prieto F, Palencia-Herrejón E, Mora-Rillo M, Astray-Mochales J, Sánchez-Seco MP, et al. Autochthonous Crimean-Congo Hemorrhagic Fever in Spain. N Engl J Med. 2017;377(2):154-61. https://doi.org/10.1056/NEJMoa1615162 PMID: 28700843

8. Grahn A, Bråve A, Lagging M, Dotevall L, Ekqvist D, Hammarström H, et al. Imported Case of Lassa Fever in Sweden With Encephalopathy and Sensorineural Hearing Deficit. Open Forum Infect Dis. 2016;3(4):ofw198. https://doi.org/10.1093/ ofid/ofw198 PMID: 27975074

9. Kitching A, Addiman S, Cathcart S, Bischop L, Krahé D, Nicholas $\mathrm{M}$, et al. A fatal case of Lassa fever in London, January 2009. Euro Surveill. 2009;14(6).

10. Atkin S, Anaraki S, Gothard P, Walsh A, Brown D, Gopal R, et al. The first case of Lassa fever imported from Mali to the United Kingdom, February 2009. Euro Surveill. 2009;14(10):19145. PMID: 19317988

11. Conger NG, Paolino KM, Osborn EC, Rusnak JM, Günther S, Pool J, et al. Health care response to CCHF in US soldier and nosocomial transmission to health care providers, Germany, 2009. Emerg Infect Dis. 2015;21(1):23-31. https://doi. org/10.3201/eid2101.141413 PMID: 25529825

12. Barr DA, Aitken C, Bell DJ, Brown CS, Cropley I, Dawood N, et al. First confirmed case of Crimean-Congo haemorrhagic fever in the UK. Lancet. 2013:382(9902):1458. https://doi. org/10.1016/S0140-6736(13)61718-3 PMID: 24243135

13. Lumley S, Atkinson B, Dowall S, Pitman J, Staplehurst S, Busuttil J, et al. Non-fatal case of Crimean-Congo haemorrhagic fever imported into the United Kingdom (ex Bulgaria), June 2014. Euro Surveill. 2014;19(30):20864. https://doi.org/10.2807/1560-7917.ES2014.19.30.20864 PMID: 25108534
14. Leligdowicz A, Fischer WA 2nd, Uyeki TM, Fletcher TE, Adhikari NK, Portella G, et al. Ebola virus disease and critical illness. Crit Care. 2016;20(1):217. https://doi.org/10.1186/s13054-0161325-2 PMID: 27468829

15. Lehmann C, Kochanek M, Abdulla D, Becker S, Böll B, Bunte $A$, et al. Control measures following a case of imported Lassa fever from Togo, North Rhine Westphalia, Germany, 2016. Euro Surveill. 2017;22(39). https://doi.org/10.2807/1560-7917. ES.2017.22.39.17-00088

16. Ehlkes L, George M, Samosny G, Burckhardt F, Vogt M, Bent $S$, et al. Management of a Lassa fever outbreak, RhinelandPalatinate, Germany, 2016. Euro Surveill. 2017;22(39). https:// doi.org/10.2807/1560-7917.ES.2017.22.39.16-00728

17. Beeching NJ, Fletcher TE, Hill DR, Thomson GL. Travellers and viral haemorrhagic fevers: what are the risks? Int I Antimicrob Agents. 2010;36(Suppl 1):S26-35. https://doi.org/10.1016/j. ijantimicag.2010.06.017 PMID: 20705436

18. Crowcroft NS. Management of Lassa fever in European countries. Euro Surveill. 2002;7(3):50-2. PMID: 12631947

19. Delgado S, Erickson BR, Agudo R, Blair PJ, Vallejo E, Albariño $C G$, et al. Chapare virus, a newly discovered arenavirus isolated from a fatal hemorrhagic fever case in Bolivia. PLoS Pathog. 2008;4(4):e1000047. https://doi.org/10.1371/journal. ppat.1000047 PMID: 18421377

20. de Manzione N, Salas RA, Paredes H, Godoy O, Rojas L, Araoz F, et al. Venezuelan hemorrhagic fever: clinical and epidemiological studies of 165 cases. Clin Infect Dis. 1998;26(2):308-13. https://doi.org/10.1086/516299 PMID: 9502447

21. Maiztegui Jl. Clinical and epidemiological patterns of Argentine haemorrhagic fever. Bull World Health Organ. 1975;52(4-6):56775. PMID: 1085212

22. Ogbu O, Ajuluchukwu E, Uneke CJ. Lassa fever in West African sub-region: an overview. J Vector Borne Dis. 2007;44(1):1-11. PMID: 17378212

23. Briese T, Paweska JT, McMullan LK, Hutchison SK, Street C, Palacios G, et al. Genetic detection and characterization of Lujo virus, a new hemorrhagic fever-associated arenavirus from southern Africa. PLoS Pathog. 2009;5(5):e1000455. https://doi.org/10.1371/journal.ppat.1000455 PMID: 19478873

24. Patterson M, Grant A, Paessler S. Epidemiology and pathogenesis of Bolivian hemorrhagic fever. Curr Opin Virol. 2014;5:82-90. https://doi.org/10.1016/j.coviro.2014.02.007 PMID: 24636947

25. Ellwanger JH, Chies JA. Keeping track of hidden dangers The short history of the Sabiá virus. Rev Soc Bras Med Trop. 2017;50(1):3-8. https://doi.org/10.1590/0037-8682-0330-2016 PMID: 28327796

26. Chan M. Yellow fever: the resurgence of a forgotten disease. Lancet. 2016;387(10034):2165-6. https://doi.org/10.1016/ S0140-6736(16)30620-1 PMID: 27229187

27. Rougeron V, Feldmann H, Grard G, Becker S, Leroy EM. Ebola and Marburg haemorrhagic fever. J Clin Virol. 2015;64:111-9. https://doi.org/10.1016/j.jcv.2015.01.014 PMID: 25660265

28. Bente DA, Forrester NL, Watts DM, McAuley AJ, Whitehouse CA, Bray M. Crimean-Congo hemorrhagic fever: history, epidemiology, pathogenesis, clinical syndrome and genetic diversity. Antiviral Res. 2013;100(1):159-89. https://doi. org/10.1016/j.antiviral.2013.07.006 PMID: 23906741

29. Linthicum KJ, Britch SC, Anyamba A. Rift Valley Fever: An Emerging Mosquito-Borne Disease. Annu Rev Entomol. 2016;61:395-415.

30. Yoshikawa T, Shimojima M, Fukushi S, Tani H, Fukuma A, Taniguchi S, et al. Phylogenetic and Geographic Relationships of Severe Fever With Thrombocytopenia Syndrome Virus in China, South Korea, and Japan. J Infect Dis. 2015;212(6):88998. https://doi.org/10.1093/infdis/jiv144 PMID: 25762790

31. World Health Organization (WHO). List of Blueprint priority diseases. Geneva: WHO; [Accessed Sep 2017]. Available from: http://www.who.int/blueprint/priority-diseases/en/

\section{License and copyright}

This is an open-access article distributed under the terms of the Creative Commons Attribution (CC BY 4.0) Licence. You may share and adapt the material, but must give appropriate credit to the source, provide a link to the licence, and indicate if changes were made.

This article is copyright of the authors, 2017. 